This interview asks how we can move to the next era of urban design, away from extractive capitalist models towards a more connected and equitable society. While there is disagreement over what exactly might come next-Young favours a new 'compassionate capitalism', while Nash argues for the importance of imagining noncapitalist models-both argue for regenerative economic models that empower people at the community level. Nash argues that Pākehā need to overcome their addiction to individual, exclusive land and property ownership, and to recognise how the violent history of colonialism underpins the ongoing commodification of land. The unfolding Covid-19 crisis lays bare the failings of our current economic model and prompts us to radically reimagine what might be possible. Young and Nash's dialogue suggests that this involves both a reckoning with our past and taking a stand in the future-imagining the world we want to inhabit as a first step towards transforming it. 


\section{Envisioning Regenerative Communities}

\section{CAMIA YOUNG \& THOMAS NASH with DYLAN TAYLOR}

DYLAN TAYLOR - Thank you for taking the time to talk with Counterfutures about the challenges and possibilities faced when envisioning prospects for housing and development in Aotearoa New Zealand. To begin, could you each introduce yourselves and briefly outline what your main concerns or interests are on this topic.

CAMIA YOUNG - I am the founder of Ohu, XCHC (Exchange Christchurch), and the project steward of Collett's Corner. Ohu is the development company, and XCHC and Collett's Corner are designed to build communities. My main concern is how we can move into the next era of urban design in a way that creates a more connected and equitable society. The last era of urban design, that of the 'production age', was, for the most part, conceived along the lines of a conveyor belt: moving people, goods, and services through space with the aim of accumulating wealth, often in the hands of a few people. The next age of urban design will be about creating places that foster connection and belonging. Underpinning this shift is a move towards business models that are regenerative as opposed to extractive. Inherent in this is the question of how we can collectively own assets and distribute wealth fairly. Housing, for me, is one part of a much greater shift. 
THOMAS NASH - My background is in campaigning and activism around humanitarian topics and armed conflict, addressing such issues as banning cluster bombs and nuclear weapons. I lived overseas for a long time and came back to Aotearoa New Zealand about two-and-a-half years ago; I have been working on ways to contribute to change and activism here since then. I got interested in housing and spent some time developing a business idea with a friend, exploring different ways of building and owning housing. It has been incredibly challenging so far-and is maybe not feasible for us at this stage. While this process has not exactly led to tangible built outcomes, it has prompted me to think a lot about the concepts of ownership and property, the financial side of housing and land. I have a role as 'social entrepreneur in residence' at Massey University, and I was recently elected to the Greater Wellington Regional Council. I want to think through questions of how to build community and how this relates to conceptions of property and the possibilities of alternative ownership models.

DYLAN - Camia, could you tell us about your work in community-led property development and the role of Ohu in all of this?

CAMIA - Ohu intentionally has two meanings: in te reo it means 'people working together', and it also stands for Office for Holistic Urbanism. Ohu, as an organisation, has three purposes: building community by building buildings; creating connected space; and contributing to the equitable redistribution of wealth. Each purpose shows up in every single one of our projects in different ways. It is useful to understand how Ohu was conceived to understand how these purposes came into play.

I am an architect by training and practiced for 13 years in the US and Europe before moving to Ōtautahi Christchurch. I am a trained visionary; I studied at two of the top architecture schools_-AA in London and Sci-Arc in LA - and practiced with two of the world-leading architecture firmsOMA in Rotterdam and Herzog \& de Meuron in Basel. I was trained to imagine a future and bring it into the present, which I think is the job of an architect. I was in my mid-30s when I was ready to find a place where 
I could test some of the things I was thinking about. I believe each of us has our own art-form, mine happens to be urban. But the urban is usually a 50- to 100-year project, because cities evolve slowly. I wanted something that could be realised in a shorter period, before I reached my mid-80s! Fortuitously, I was invited by Derek Kawiti, who I had studied with in London, to teach at the University of Auckland in 2011. This was shortly after the Christchurch earthquakes, and I was hired to teach a course I called 'Future Christchurch'. I visited Christchurch before teaching, because, of course, you can't teach something you don't know anything about. I walked the city for a month: it was surreal and felt post-apocalyptic.

I ended up moving to Christchurch, seeing it as possibly one of the greatest opportunities of my lifetime. The city would be going through a pivotal period of change, which means it would go through in around 10 years what would normally take about 30 years or more of development, making it an exciting place for somebody who wanted to be part of building a $21^{\text {st }}$-century city.

Because of immigration restrictions, I wasn't allowed to practice as an architect, so I ended up volunteering my time and doing a whole range of projects. It was through these projects that I started to see evidence for the future of architecture, which informed the purposes underpinning Ohu's projects. I was the lead designer on the Pallet Pavilion, which was about 400 square meters and was constructed from blue shipping pallets by volunteers. It was built in the centre of the city while every building around it was literally being demolished. This little pavilion was one of a few public spaces that had gone up, along with the container mall. The city was undergoing demolition for years, and we were this tiny bastion in the city centre where you could gather in a public space. But the space was secondary to the community that we built. This was the first time that I realised you can build a community by building a building. That's the evidence, for me, of what the $21^{\text {st }}$-century city could be. The experience of working on the Pallet Pavilion became foundation number one.

The second foundational experience came with XCHC, whose purpose is to cultivate a creative ecology. We brought together in one building 
production spaces, a showcase space, a bar, and a café-things that would normally occupy separate spaces. It has worked beautifully; it's incredible how strong the community that has formed there is. It's exciting to see this model working, and we will now look to scale up XCHC and extend it into other areas.

With XCHC, we're working with the notion of connected space. We have passed through the production age, which in the urban realm involved separating functions, with the city working like a conveyor-belt moving goods and people between discrete and separate points (from housing to work, on to consumption and entertainment, and back to housing). In the age of belonging, the one I believe we are moving into, it's about bringing together the things that were separated in the last era, which is what connected space seeks to do. It's in the moments when people meet each other that they develop and mature relationships. XCHC is a working model that evidences the possibilities of connected space.

The third purpose, which is the hardest to achieve, is recognising that we are in an era of extreme wealth inequality and multi-dimensional systems collapse, and that these are related. We are transitioning from an extractive era-in which businesses seek to maximise profits by depleting resources and generally consolidating wealth into the hands of a few people-into an era that is regenerative, where businesses are designed to replenish the resources upon which both communities and the environment rely. What we are starting to see, and what Ohu is committed to, is creating regenerative economic models that distribute wealth in equitable ways and replenish human and natural resources - and that's a critical piece of the equation if we want to move into the next age, the age of belonging.

DYLAN - I'm interested in what you mean by the term 'community'?

CAMIA - I define community as a group of people working together with a common purpose.

DYLAN - How much durability does community, as you define it, have? I 
tend to think of community as a group of people that are tied to a particular place - that there is a shared experience of space and time that contributes to people being a community. But then I can also imagine, in the context of people coming together to build something, that the formation of a community is facilitated by a space, but they are not necessarily tied to it - the duration of time is less important. We can say: 'Here is a collection of 100 individuals, working together, they are a community that we can identify at this point of time'. But will they still be there in five or ten years from now?

CAMIA - I have seen that there are place-based communities and there are purpose-based communities; there may be other types of communities as well. My work is focused on the purpose-based communities, and as long as the purpose is solid, and people know what they are stepping into, people can come and go; that's okay-it's even healthy for a community. And it's alright if a purpose-based community dies, we don't have to hold on to them in perpetuity. Some projects are short lived, like the Pallet Pavilion. What happens in such cases is what I imagine to be a flow of energy: a certain energy comes together, connections are generated, and often when that project is ready to finish that energy goes somewhere else, usually into another project because people will have learnt something special about belonging to a purpose-based community and they tend to seek it again. So we're talking about something that's evolving, it's a dynamic rather than a fixed notion.

Here, I think of the developmental psychologist Robert Kegan's work. He suggests that as we enter old age we pass through later stages of learning. ${ }^{1}$ Learning isn't something we just do in our first 20 years of life, it's something we continue to do. The human mind passes through different stages of development, and as we grow older, we learn to belong to many communities. This growing desire to belong to many communities is what

1 Robert Kegan, "What "Form" Transforms? A Constructive-Developmental Approach to Transformative Learning,' in Learning as Transformation: Critical Perspectives on a Theory in Progress, ed. Jack Mezirow (San Francisco: Jossey-Bass, 2000), 3-34. 
drives the community-minded property developments I am involved in; it's what makes them possible, because you don't belong to one, you belong to many. Each community provides a different kind of return, it could be financial, social, or some other form of meaningful return.

DYLAN - Could you unpack some more what you mean when you suggest that wealth is, or will be, distributed in more equitable ways in the projects you are discussing. What does this mean in practice? And what does it mean for the investors? Because we tend to think of investors in a capitalist economy as people chiefly motivated by a desire for financial returns.

CAMIA - In a regenerative economic model we would replenish resources rather than deplete them. We are testing this in the case of Collett's Corner. The idea is that a community owns the building, and they would therefore benefit from the profit earned through rents. In an ideal world we would ring-fence the community to the purpose of the building, but if we did that with this development, we would not have investors, nor would we have found banks willing to loan money. We are taking one step in the direction of change, but we admittedly have a long way to go to create truly regenerative property developments. Each project we do will be bolder and we will be able to take bigger steps as we gain momentum. Collett's Corner is our first step towards this kind of change.

What we are trying to do, in say 10 to 30 years, is distribute wealth more equitably. If we are to achieve a truly flourishing society, we'll each need to have our basic needs covered. The aspiration is to deliver a universal basic income that comes from belonging to many communities. It's not coming from government, it's coming from investing in communityminded property developments, or other community-minded businesses. If we were all able to invest in regenerative economic models, then in five to ten years we would each be getting a passive income that's distributed equitably. We would all be getting a little bit, rather than a few people getting a lot.

Unfortunately, my hypothesis (without any deep-data analysis to back 
it up) is that the only people investing in Collett's Corner have discretionary income, which means they're wealthy investors and we are not really tackling the problem we are wanting to address yet. What we established in the constitution for Collett's Corner is capping the amount that people can own-that's one way that we were able to work towards redistributing wealth: no one can own more than 10 percent of the company. My hope is that with our next project, we can tackle how to balance the investor base. The other disappointing thing, in looking at our investors, is the femaleto-male ratio, which is another of these issues around equitability. It may be that some couples are investing under the man's name, but it appears on paper that men are investing at a rate three-times higher than women, which is no surprise given the disparities in pay scales between men and women. I would love to do a project in the future that is women-owned.

To answer the question of what's in it for the investors who have come on board, we did an investment memorandum and approached investors through PledgeMe-we couldn't open the opportunity to the public because of financial regulations. In the memorandum, we had a financial analysis predicting an average 7.5 percent return over a 10 -year period.

THOMAS - While it is a high rate of return, it is less than that aimed for by extractive property investments, which tend to look for a rate of return greater than 10 percent. You could make a lot more money on Collett's Corner if you approached it in an extractive way, but your approach is very different.

CAMIA - I explored ideas around ethical investment and capped-investment returns, but many things that I have wanted to do with this project have been pared back. It's hard to keep fighting for what you believe in. Every time I wanted to really push things out there, I got told 'no, no, no'. But I understand why, otherwise we wouldn't have attracted early investors. My ideal vision was that nobody would get a financial return, that investors could only hold their shares, and that the only thing they would get was that these shares would appreciate. Any financial returns would go to serve the community's purpose. But my vision of the kind of world we are going to be 
living in is way too futuristic for most investors today.

We researched the ethical property model, which are commercial developments for social entrepreneurs that usually offer a 4.5-5 percent return. But there are new social-impact funds out there that demand 12-14 percent returns. I wonder what they are going to invest in? That rate of return doesn't make any sense to me. Okay, it is high risk, but is that really how this works? Because you're actually just perpetuating the problem you're trying to solve.

DYLAN - You mentioned that your work is seeking to develop regenerative economic models, which replenish the resources on which they thrive rather than deplete them. What does it mean to replenish social resources in this context?

CAMIA - The point I have reached in thinking this through is that the purpose of regenerative businesses is to serve the community in some way. For example, at $\mathrm{XCHC}$ we support creative entrepreneurs to thrive, and all of our profits are used for supporting and developing creative practices. The purpose emerging with Collett's Corner is what I'm currently calling 'The Future of Health' (we don't have the right name yet). Over two years, in the lead up to developing Collett's Corner, I listened to people from Lytteltonconducting surveys, meeting one on one with locals, holding workshopsand what I heard again and again was, 'we don't want any more bars, we don't want any more bars'. Okay, I heard what people didn't want, and I had to hear that in order to find out what was wanted. At the same time, I was becoming aware of negative mental-health statistics, which are severe across New Zealand, but particularly so in Lyttelton, where there's a high rate of youth suicides. I reflected this back to the community, asking, 'what do you think of creating a place where we can come together and work on our mental and physical wellbeing?' And when I raised this question in interviews and workshops, I had people in tears, they were so moved by the idea. And I was like, 'oh, I think we just found the will'. That's the regenerative piece, creating something that the community wants, that will 
bring people together, serve them, and replenish them. That's as close as I can get to drawing out the social regeneration side of things at this point. I am learning as I go, and it takes a long time to discover what is at the heart of a community.

DYLAN - Throughout this conversation, you are making it clear that you are having to work within the limitations of the capitalist economy, as well as with the mind-set of where people are at now, but it is also clear that you are directed towards an ideal. Could you explain some more what this ideal is? If everything that you hoped for were to happen, then where would it lead?

CAMIA - Okay, imagine a future where you are not working a 9-to-5 job, and you can belong to many communities of your choosing. Each community would provide you with a meaningful value, a return of some sort. What this might be is probably something that we have not identified yet, because right now the only return most people can imagine is monetary. But imagine a future where there are many different kinds of return. In this future scenario, we may have moved past this zero-sum notion of production. We can no longer get richer. Productivity is not increasing (we're no longer seeking to constantly make or own more things), but the price of things is decreasing, and we have learned to share resources. A point is reached where things can be produced for essentially zero and the return value is near zero. If we were to reach such a point, we could bypass the logic of extraction, because everybody could access what they needed. Then we would have a choice of what we wanted to do, and that is where things get interesting. I believe we all have a creative calling, a gift, a desire of some sort in us. If we can nurture that idea and draw out the potential in each of us, we would move out of the scarcity mind-set and into one of abundance.

But right now, we are in the middle of a systemic collapse. The collapse isn't coming, we're in it. What I've learned in the post-earthquake context is that life goes on. We don't necessarily feel like we're living through a collapse because the human brain adapts quickly, the downside being that 
we sometimes don't realise where we're actually at. History suggests that a collapse comes with a revolution. So, we will see. But we might also just wipe ourselves out. We have a choice at this stage: either continuing as we are and possibly becoming extinct or building a future that is fundamentally different. All of the disruptions we are currently experiencing are leading us towards that future-in conceptualising it this way I'm influenced by the work of Charles Eisenstein. ${ }^{2}$

DYLAN - So, to put labels on things here, are you envisioning a postcapitalist economy, or a different type of capitalism?

CAMIA - I call it 'compassionate capitalism'.

DYLAN - To me, that sounds like an oxymoron; could you explain what you mean by that?

CAMIA - This notion is the essence of what I have been talking about: businesses becoming regenerative rather than extractive, businesses are designed to replenish resources rather than deplete them. I think compassionate capitalism is an important framing, and even more so given our current situation. I take a Darwinian viewpoint on economics - that is, the economy evolves and adapts. Compassionate capitalism evolves out of extractive models — rather than breaking with them — and it tends towards the replenishing of resources. Not only is this possible, but it is vital, and we are actually seeing it unfold in the current moment.

I envision a world that is no longer constrained by strictly monetary values. We can move into an era of abundance, because we will figure out how to live holistically as a society, as a planet, as a species with all of the other living beings in the world. And we live in balance with our planetary means. We would have learned two things: to share, which is a communication shift; and to know what is enough, so that we no longer

2 Charles Eisenstein, The More Beautiful World Our Hearts Know is Possible (Berkeley: North Atlantic Books, 2013). 
push beyond our planetary boundaries. I believe these are the two critical pieces for getting us across the bridge and into the future. Most of the companies that I see emerging in regenerative spaces are addressing these issues. Each of us may belong to 10 or maybe even 20 communities in the future, and they will be fluid. Some will grow, some will decline, and that's okay, that is a part of life. It will be celebrated when new communities are born and when others die.

DYLAN - If you are thinking about these multiple, different communities, and the decision-making that will be taking place at the community level, then what about social organisation on a larger scale? Currently, a lot of social organisation-laws, regulations, decisions about key infrastructure and social-service allocation-occurs at the level of the state, which in turn must orientate itself on a global stage. How does this long-standing topdown approach intersect, if at all, with the type of decision-making you are envisioning across these multiple community spaces?

CAMIA - I have two comments on that. First, disruption hasn't hit government yet. Government is still, essentially, a pyramid model. It's caught in the last century, in the production-age version of a commandand-control organisational structure. This model will change; government will likely become much smaller than it is now, because communities will become much more capable. You will be able to divest responsibilities to communities, and the communities will be multi-layered and very interconnected.

The second point concerns the social process, and this is one of the most interesting emergent fields of our time. In the last century, cities were shaped by the planners, engineers, architects, and developers. In this century, cities will be shaped by what I call the 'community weavers'- the people who bring us together. They are the ones who will shape this next era, because it will be a hyper-social era. This community-weaving tendency has long existed, but it is about to intensify; there will be an exponential curve in innovation in this field. Ohu has four pillars that guide our work: social 
structures, financial structures, legal structures, and property development. We find that the most innovation is happening around social structures, addressing the question of how you bring people together well.

DYLAN - Thomas, while we're discussing large-scale possibilities, I was wondering how you are thinking about issues at this level?

THOMAS - The driving force in all of this, for me, is our relationship to land, property, and housing, which I feel we have got really badly wrong. Andro Linklater, in his book Owning the Earth, has described ours as a 'private property society', and argues that our current ownership-based society is a 'bizarre aberration alien to most of humanity'. ${ }^{3} \mathrm{He}$ reaches this conclusion having surveyed the broad arc of human history across different parts of the world, and how people have conceived property ownership. The system we currently have was largely developed by a colonial, imperial Britain in the 1600s to 1800 s. It consists of carving up pieces of land and selling them off as commodities for exclusive ownership by individuals and companies. We have an extractive capitalist model that has been incredibly successful at making a few people grotesquely rich and maintaining a whole bunch of other people in a scandalous state of class-based destitution.

We have an acute experience of that in Aotearoa New Zealand, because this country was carved up in exactly that way. It happened at the barrel of a gun, with the confiscation of land following the Crown's provocation of different hapū and iwi. I think there's a connection between that historythe history of our relationship to land, property, and ownership-and the extremely acute experience of the commodification of housing that we have in this country. This commodification is probably as acute as it gets in the Western world, as we have ten times more investment dollars in housing than in any other form of investment.

CAMIA - The notion that your bank account is your house.

3 Andro Linklater, Owning the Earth: The Transforming History of Land Ownership (New York: Bloomsbury, 2013). 
THOMAS - This is an extremely unproductive notion. Even if you want to buy into arguments in favour of productivity and capitalism, you have to admit that we have the worst way of organising capitalism. We basically put all our money into totally non-productive assets that cannot be used to support, say, the development of companies or collectives that might actually do something useful to solve the problems we face in phasing out fossil fuels, and living, eating, and getting around in ways that use far less energy.

We have a terrible addiction to individual, exclusive, land-and-property ownership in Aotearoa New Zealand, most of it designed around urban sprawl that locks in our dependence on individual fossil-fuel-powered cars. I think there's a cultural element to that, in particular for Pākehā, which is going to be extremely challenging to overcome. I experience this myself as a renter in Wellington. I would really rather get out of this situation. I don't want to continue with these scandalous extractive-renting situations, where owners, probably through inheritance or luck, maybe through hard work alone, are pretty much effortlessly enriching themselves through our renting from them. How do we get out of this situation? Obviously, the first alternative that comes to mind is owning our own house. But there must be some other way. This situation is what led me to start thinking about alternatives.

I think that what we are missing most of all in this country are credible alternatives to the extractive-renting and ownership models. That is why I think what $\mathrm{Ohu}$ is doing, and what other people are doing with co-housing, is important, even if on the face of it they don't necessarily break from the ownership model as much as we would like. The importance of these initiatives lies in seeking to open alternatives to the stark, binary choice that we currently face of either renting or owning. ${ }^{4}$

We need to challenge the notion of ownership. What do we mean, what do we want, when we say we want ownership? Because supposedly everybody wants ownership, right? Why? Is it something people want to pass on to their kids? I understand that, and would feel the same, but

4 See Cole, 'A Case for Universal State Housing,' this issue; and Southcombe, 'Re-socialising Aotearoa New Zealand Housing,' this issue. 
this country has zero tax on inheritance, which is problematic, because it entrenches inequalities across generations. Is it that people want an asset that they could profit from through speculation? Well, if that's the case, then that's actually the problem and needs to be challenged. Is it that people want something that they feel they have a stake in, and can't be kicked out of? We can find ways to do that outside of the model of ownership and being saddled with debt. For instance, we could fix that with various forms of security of tenure, where you can have a lease on a house for your whole life, for example.

Residential leases are a model that could work here. We currently have commercial leases in Aotearoa New Zealand, but we don't have a culture of long-term residential leases, which in other countries is perfectly normal. If the lease holder was a not-for-profit entity-say, the government, council, a Māori organisation, or a community-based organisation-then that could allow people an affordable opportunity to occupy a place for their lifetime. This is just one possible model we could be exploring. I don't pretend to have it all worked out, but the most important thing is that we develop some working alternatives.

A major problem when pursuing alternatives are the banks, who are rapacious and enrich themselves by charging interest. One of the reasons we have had an explosion in house prices is because banks have said: 'the more expensive the property, the more money I can lend you, and the more interest I can earn'. The world is awash with cheap credit at the moment, with a lack of profitable places for it to 'land'. So, banks may engage in 'force-feeding' credit to consumers via aggressive marketing campaigns, and this interacts with a number of other dynamics in Aotearoa New Zealand to fuel the housing market.

It is common to hear people say the market is broken. The market is not broken. The market is finely tuned to achieve precisely what it is designed to achieve, which is to effortlessly enrich the banks and the rentier class at the expense of everybody else. Yet we don't really talk about this as a country, because we've been hyper-normalised into thinking that this is just the way it is. There needs to be a non-capitalist model in play as part of 
a long-term re-imagining of what is possible.

The Preston model is worth considering. Preston is a town in north-west England, in Lancashire. It completely redesigned its approach to managing the city, community, businesses, and the economy after the financial crisis in 2008 , owing to a project for a big shopping mall falling through. Preston was left in the lurch; their long-term development strategy had been based around this massive shopping mall. As a result of that-and this ties into what you were saying earlier about Christchurch, Camia-this crisis opened an opportunity for a different model of development for the town. Preston has now successfully pioneered a model of community-wealth development, in which 'anchor institutions' play a key role. These are the institutions and organisations that can't move and have the biggest budgets in the town-like the hospital, university, and council—and they use their procurement power and mutual funds (like pension funds) to support local businesses and worker-owned cooperatives. This model regenerates and circulates the resources being used, in contrast to the extractive model which is driven by a race to the bottom in terms of price.

For me, the Preston model is a really good example of how communitywealth building can not only provide a really successful outcome economically and socially, but it can also provide an example for others to follow. I am really interested in thinking about how we could develop some models like this in Aotearoa New Zealand. If you look at the papakāinga model, you can see that many Māori communities are way ahead of Pākehā conceptually. It would be good to see what kind of tikanga-based projects could be pursued. Jade Kake is an inspiring thinker, writer, and architect working in this domain. Her 2019 book, Rebuilding the Käinga, is a key text describing the contemporary developments in Māori housing. Kake describes papakāinga as 'housing alongside communal facilities, generally on ancestral land'. ${ }^{5}$ There are examples of this being pursued by iwi, hapū, and whānau all around the country, from dense urban centres like Auckland

5 Jade Kake, Rebuilding the Käinga: Lessons from Te Ao Hurihuri (Wellington: BWB, 2019), 11. See also, Kake, 'Spatial Justice—Decolonising Our Cities and Settlements,' this issue. 
through to smaller towns and rural areas. Papakāinga take various forms and grapple with the constraints of a capitalist system and commodified housing market in different ways. There is a tendency towards affordability and social and environmental harmony, and Kake talks about papakāinga becoming 'the core unit of political and economic activity'. ${ }^{6}$

CAMIA - Imagine that we don't own land, rather we are its stewards, and it's not an individual private gain that's being pursued, but rather the community's.

THOMAS - That's the entry for me into all of this, that word 'ownership'.

CAMIA - Yeah, what does that really mean? 'Ownership' is so last century; this century will be all about 'stewardship'.

DYLAN - In terms of pursuing alternatives, it's useful to map the obstructions that need to be overcome. The banks are one obstruction that has already been discussed, which presents a material obstruction-access to money - that has a whole conceptual edifice sitting on it as well. Another obstruction coming through in the conversation is the Eurocentric notion of what ownership is, which is something you both want to challenge. Are there any other obstructions that we should be mapping, and how might these be countered?

THOMAS - Individualism, which I think is wrapped up in the concept of ownership. We have been battered into an individualised existence, and the built environment reflects and reinforces this.

CAMIA - Insurance is another obstacle, particularly in an era of climate change, and the country's earthquakes. Insurance has become very expensive and difficult to get and is often a prerequisite when seeking to develop housing. So how about a cooperatively owned insurance company?

6 Kake, Rebuilding the Käinga, 13. 
THOMAS - Yes, this is what people had in the past. They had mutual funds, or building societies, which did insurance, savings, and housing loans. These got hoovered up by banks, who then wound them up as they did not make enough profit.

CAMIA - Another obstruction is how easy it is to blame others when confronted with these problems around housing and development. We all point outwards. I find that quite fascinating, because we are the others. We put these systems in place, we are part of these systems, we can't deny that. I look to the government, which holds an enormous amount of control, and their policies are not keeping up with where we are at. We need rapid change. Or consider the banks: their primary motivation is to make more money. We have to interrogate this motivation. We need to ask, 'what is the motivation, what are the values that I am governed by?' In asking such questions, we can reach a turning point.

I think that what's happening — and I am new to this territory-is that we are going through a massive evolution in our emotional development as a species. I am seeing this in the way we are starting to develop our emotional literacy and communication around challenging emotions, so that we can try to get past some of the obstructions that have been holding us back as a society. The individualisation fostered through how our urban environments have been set up is a by-product of what is limiting us in our own social interactions. Once we start to create the places of connection and belonging that we discussed earlier, we are going to have to evolve emotionally. We will have to get much better at communicating and relating to others. This is the internal barrier we all need to start working on. I turn to both Brené Brown and Pema Chödrön, to name but two people that I learn from, in order to understand emotional development. ${ }^{7}$ The legal structures that dominated the last century were concerned with how I can protect myself from you, and vice versa. This century is about

7 Brené Brown, Braving the Wilderness: The Quest for True Belonging and the Courage to Stand Alone (New York: Random House, 2017); Pema Chödrön, Comfortable with Uncertainty: 108 Teachings on Cultivating Fearlessness and Compassion (Boulder: Shambhala, 2018). 
how we are going to work together, and that's going to take some emotional development.

THOMAS - Two other obstructions that come to mind are food systems and transport. Food systems, because most of us have been separated from growing, gathering, and making food. That is a key part of how we relate to our land, but many of us don't really see it. A good vision for housing and land has us growing food in the places where we live. This is something that really struck me when I visited the community at Ihumātao in August 2019: people were growing their own food there. The other thing is transport: how we get around, how we build things, how we build our homes in the right places. We need to build in a way that liberates us from the car dependency imposed on us by urban planners and the automobile and oil industry in the second half of the $20^{\text {th }}$ century. Cars are convenient, but we are addicted to them-we have more cars than drivers in Aotearoa New Zealand. The pressures of this status quo generate a powerful obstacle to changes in our housing set up. We need more space for walking and cycling and way more public transport.

CAMIA - And energy, it comes down to using renewable energy and sharing resources, and that these should be collectively owned.

DYLAN - We are entering the second week of the Covid-19 lockdown as we put the finishing touches to this interview. Economic commentators are forecasting a depression that may be as devastating and long-lasting as the Great Depression of the 1930s. On the political front, it is being greeted by some as a moment of peril, as seen, for instance, in authoritarian-leaning rulers using this state of exception to further entrench their power, and with the lockdown of borders reinforcing the xenophobic rhetoric of nationalist far-right movements. It can also be viewed as a moment of great possibility. The Covid-19 crisis has shown our capacity to collectively respond to 
a crisis, and this may see a turn toward, among other things, a 'Green New Deal' as a means of addressing both catastrophic climate change and economic crisis. ${ }^{8}$ How does your analysis of the early days of the Covid-19 crisis fit with the arguments you have advanced earlier in this interview? Are you leaning toward 'peril' or 'great possibility' when thinking about the impacts on housing, urban regeneration, and community development?

THOMAS - Sadly, the peril is already here for many people. The pandemic brutally exposes the deep, enduring inequalities in our society. People with low or insecure incomes, people victimised by domestic violence, and people with disabilities or health conditions are struggling more than ever. Meanwhile, minimum-wage workers keep us all going by turning up to their jobs at supermarkets and other essential services, putting their own health at risk. And it's noticeable that the government gave dedicated support to home-owners with mortgages, but not to renters.

So the first principle for the recovery is to recognise that our way of organising the economy has failed people and must change. If we act on that principle, we have a once-in-a-lifetime chance to rebuild our economy in a way that benefits all people, that is climate safe, and that restores our natural environment. This will be hard work, but it is totally doable and totally necessary.

CAMIA - I agree with Thomas, we are at a crossroads: we can go back to 'normal' and run the risk of driving not only ourselves but the majority of the world's species to extinction, or we can transition to a way of being that recognises the intricate balance of all living systems. We have a precious

8 The term 'Green New Deal' (GND) refers to Franklin D. Roosevelt's New Deal, a set of economic and social reforms and public works responding to the Great Depression. The GND gained impetus as an idea in the wake of 2007-2009 Global Financial Crisis, with it posited as a means of responding to this crisis, along with peak oil and climate change. The idea has been picked up by the Labour Party in the UK, some members of the Democratic Party in the US, and various Green parties around the world. One Left critique of the GND is that it is still too wedded to capitalist imperatives of growth and consumption. See Robert Pollin, 'De-Growth vs a Green New Deal,' New Left Review 112 (2018): 5-25. 
opportunity to fundamentally change our systems so that they work within the planetary boundaries, and to create a society premised on compassion and kindness. The bridge between here and that future world is one of consciousness. I think of how Tühoe won their case with the Crown: they worked with their community for two years, together they imagined the world they wanted to live in, and then they made their case from the perspective of that future. It was not about moving towards something; instead, they stood in the future and spoke from there. Our job now is to imagine that future and work from there together. 
THROUGH THAT WHICH

SEPARATES US

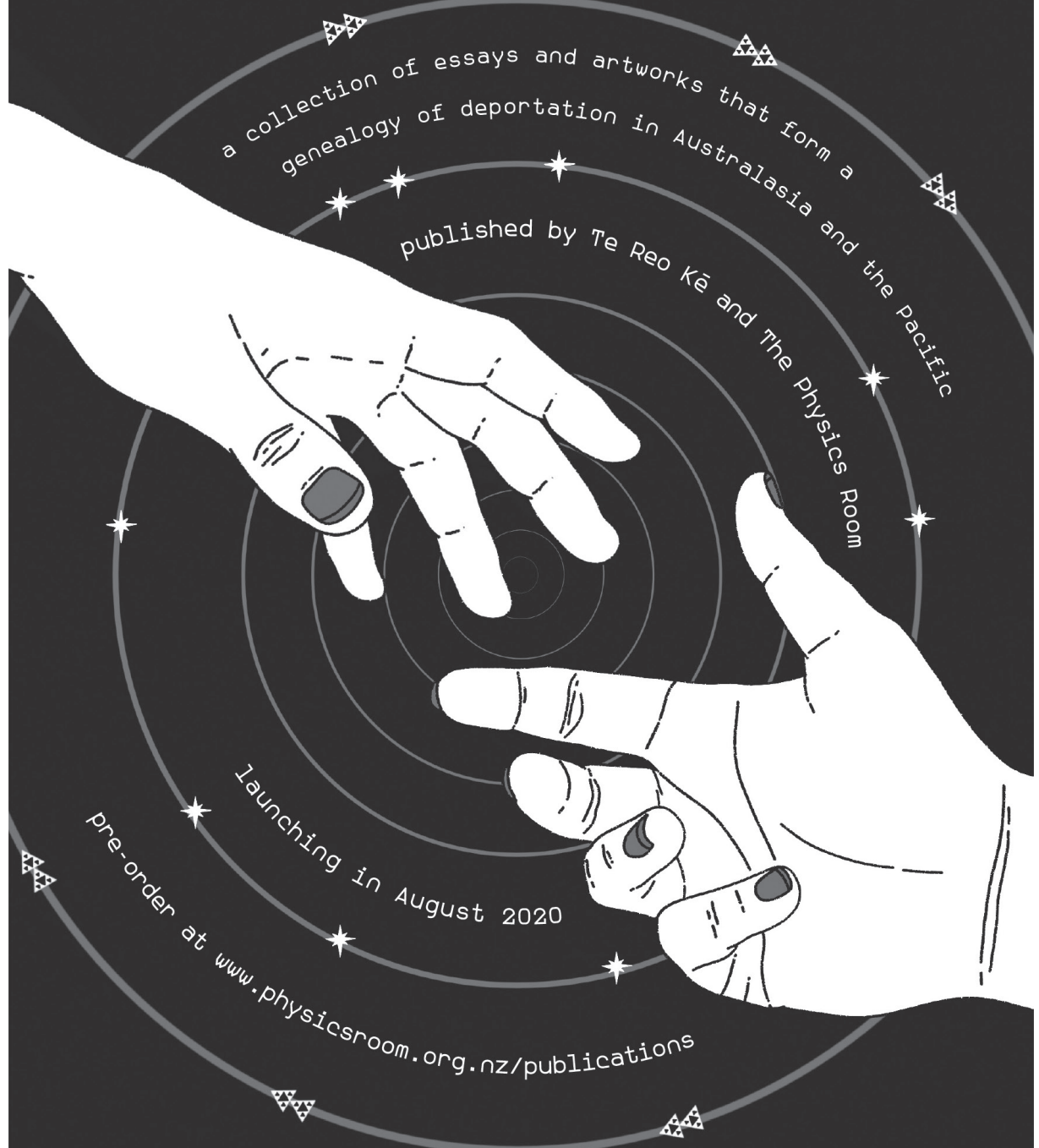

